\title{
Surviving structural violence in Zimbabwe : The case study of a family coping with Violence
}

Otrude N. Moyo

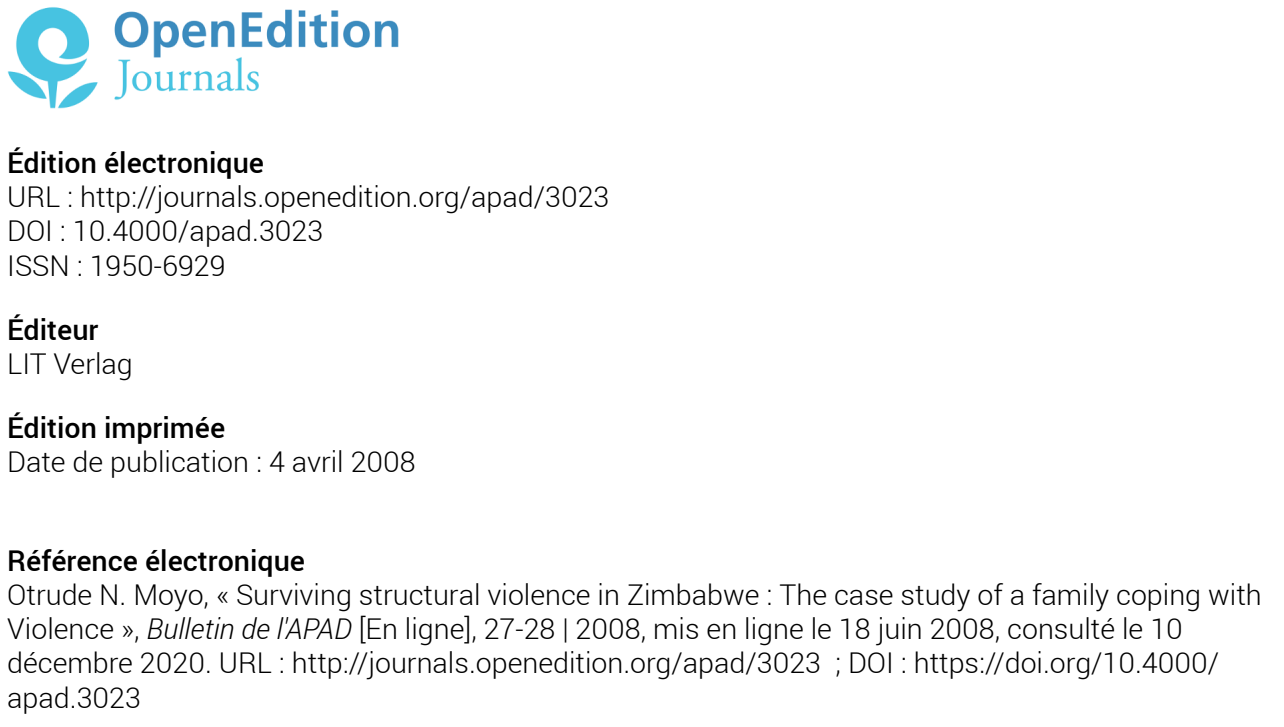

Ce document a été généré automatiquement le 10 décembre 2020.

Bulletin de l'APAD 


\title{
Surviving structural violence in Zimbabwe : The case study of a family coping with Violence
}

\author{
Otrude N. Moyo
}

Research on violence in Zimbabwe has been limited despite the visibility of state violence against citizens that has been broadcast by the international media since 2000 (Chitiyo 2000). Zimbabwe has a history of violence both in the public and private spheres (Sokwanele 2006). In the public arena, pre-colonial narratives speak of ethnic rivalry but it is the legacy of the violence that was ushered in by colonial occupation that has been instrumental in the structural violence expressed and experienced within the public and private spheres that has marred Zimbabwe's post-independence experience.

What is violence? This article addresses this question by providing a situated answer. In an edited discussion of international perspectives on family violence, Malley-Morrison (2004) suggests that we all have implicit theories about the meanings of social phenomenon, like violence. By implicit theory, Malley-Morrison refers to the notion of personal constructs of meaning about a phenomenon. According to this social constructivist view, people actively construct understandings about themselves, others and relationships. We are not just passive learners of facts about the social world (Malley-Morrison 2004: 5). As such, implicit theories about violence develop through one's experience of their social environment and the stories unfolding there.

In this chapter, I argue that family violence is a manifestation of structural violence, associated with a political economy that has sacrificed many of its citizen's livelihoods. Life in Zimbabwe has historically been lived through structural violence and the nature and consequences of this violence are visible in all aspects of the social life of Zimbabweans. Using the social constructivist perspective where implicit theory informs what I view as violence, I argue that Zimbabwe's heritage of violence in the political economy creates a breeding ground for family violence. Within the private sphere of home, role, expectation, status incongruency and competition between 
family members for limited resources all put pressure on family life (Goode 1971, Campbell 1992) and this creates an environment in which family violence is likely to erupt. Given the socio-historical context of the political economy in Zimbabwe, I argue that the family is a power system of unequal members like any other but, in an environment of inherited violence and when an individual within that system does not have resources, he or she is more likely to use violence to get what they want. The connection of the socio-historical context of structural violence helps to explain the correlation between material deprivation and family violence in the case presented in this discussion. After the European invasion and occupation of Zimbabwe, violence became an active instrument to entrench coercive settler power and rule. But violence also became the instrument for dislodging settler power and rule and achieving Zimbabwe's political liberation (Sokwanele, 2006). The tentacles of violence reach far and wide. Financial hardship and poverty have historically been the most interfering and destabilizing factors for the vast majority of the population in Zimbabwe and have contributed to an elevation of violence on and within the family and at a macro level, which I call 'structural violence'.

4 I begin the chapter with the socio-historical context of the political economy of Zimbabwe, which provides a summary of major issues related to the country's structural violence. This is followed by a family vignette in which experience and voice reveal conceptions of family violence as embedded in a structurally violent environment. The family whose experience is shared here was encountered in my earlier work relating to an understanding of families, their work and livelihoods in Bulawayo, Zimbabwe (Moyo 2001). However, this work did not directly research violence per se but family well-being. The entrenchment of violence in Zimbabwean society and an encounter with a family of older adults living with an adult son who was 'troubled and troubling' led me to consider sharing their experiences to show the nature of structural violence as it is experienced in family interactions. What forms does structural violence take within the family? What do elders who are experiencing violence say about it? What does the child who is perpetuating the violence feel?

5 Using a case example, I recount a historicized story of the experiences of structural violence in one family. The narrative is mainly told from the vantage point of three family members, the fifty-six-year-old mother, the father who is in his late sixties and their twenty-six-year-old son. The issues that are perceived to have precipitated the violence and the different forms of violence provide texture to the complexity of violence as a social phenomenon. The experience of this family is situated in the socio-historical context of Zimbabwe to connect interpersonal violence to structural violence. The intention is not to generalize the experience of a single family but to highlight the particular experience of one family in understanding violence, a visible but hidden social problem in Zimbabwe. I have used a broad definition of structural violence to avoid a priori normed naming of family violence but through the vignette we glean a complex understanding of what is considered family violence, in this context. Violence is inherited when the perpetrators are excused and the victims are blamed for not avoiding violence (Sokwanele, 2006). Violence can also be silent and loud; silent violence refers to the threats, the coercion, the insults and the deep scaring that has no physical marks, and the loud violence refers to the physical harm to people, to their property (Chitiyo 2000) and their environment including the social environment of the community. 
Defining structural violence and the embeddedness of family violence

Like any social phenomena, family violence must be understood within the socio-cultural context in which it occurs. Interpersonal and intrapersonal violence in Zimbabwe takes place within a context of structural violence. Structural violence refers to a mode of human relations involving the domination and exploitation in economic, social, political and psychological terms between individuals, between social groups and classes within and beyond societies, and globally, between entire societies (Gil 1998). Examples of structural violence experienced as personal violations and interpersonal violence are numerous in Zimbabwe. Consider the visibly segregated residential spaces that once entrenched the divide between the Africans and the whites. Now, the divide marks the material-rich from the poor. The organization of living space in Zimbabwe speaks to the profound consequences of the racialization of the political economy, meaning the use of race as a means to foster unequal development at all levels of society (Moyo 2001). The history of the racialization of Zimbabwe's political economy gave 'white' privileges of power in controlling the economy and polity from colonial occupation in the 1890s until Zimbabwe's independence in 1980. The consequences of this control led to devastating socio-economic conditions for the African population that suffered massive poverty, high unemployment, poor housing and a lack of access to health care (Mandaza 1986, Moyo 2001). Unfavourable socio-economic conditions have a tendency to put pressure on personal and intrapersonal relations leading to tensions and high crime rates involving forms of physical, psychological, social, environmental, political and economic violence.

7 In a country marred by poverty, it is not uncommon for a person to be attacked by another on the streets. People endure insults of all sorts and pickpocketing occurs during the constant body searches that people are forced to go through by state functionaries i.e. the police and the army and by private security guards supposedly protecting individuals. Imagine a knife being held to your throat as you are ordered by assailants to hand over your purse and even the clothes you are wearing. In the privacy of one's home, thieves working in gangs and those who make a living by hassling (otsotsi) threaten families by breaking and entering the sanctuary of their homes. Burglaries are the order of the day. When using public transportation a person's dignity is threatened as people are packed into vehicles like sardines. Family members, neighbours and friends accuse each other of witchcraft, and public brawls are not a rarity. In social care and public life shaming is used as a way of care. At home and at school children are beaten into submission. Children learn young "that it is acceptable; it is the privilege of the perpetrator and must be suffered and tolerated by victims. Not because the perpetrator is right, but because they have power ... children learn to become victims of superior force backed by the authority of a revered institution" (Sokwanele 2006).

8 In schools, a few select children learn how to be in charge of and discipline other children through the prefect system, which has been passed down from the English public school system and is the moulder of colonial officials (Ibid.). These children are permitted to exert considerable brutality through physical punishment, exertion and psychological punishment that often entails shaming and humiliation. If you are the victim, you are supposed to endure such treatment as perhaps one day you will be able to get back at those who tortured you by torturing others. This is the inherited violence 
that is structurally entrenched and carried over to the public and private spheres so that everyday lives are characterized by structural violence and a mode of human relations involving domination and exploitation in economic, social, political and psychological terms in everyday situations. This is not to say that this is the norm but people have become accustomed to violence. Outbursts of violence from the state, fellow citizens and institutions of public life have become part of everyday life. However, no social violence is as humiliating as that perpetuated by family members, particularly one's own children and grandchildren. In the privacy of family life, scars of structural violence are more visible in interpersonal and intrapersonal familial relations. Concha-Eastman (2001) and Okulate (2005) point out that the intentional use of force against another person in close relationships or otherwise is now acknowledged as a universal public-health problem. The connectivity of structural violence and personal violence often gets missed.

Socio-historical context of the political economy of Zimbabwe

Family violence in Zimbabwe must be located and analysed within the wider context of the political economy of Zimbabwean society to understand the structural and personal expressions of violence. The Republic of Zimbabwe came into existence in 1980 out of the struggle for African rule that spanned over a century against white settler governments whose roots were entwined in European imperialism and British colonialism. In this case, the use of physical violence was historic. The scramble for Africa by Europeans, the use of force, the expropriation of African lands and the massive relocations of African peoples to create «white territory» illustrate the horrific physical violence of occupation.

The psychological, social, political, environmental and economic nature of structural violence is exemplified by the racialization of the political economy of Zimbabwe. For the most part African families and their livelihoods occurred within the context of a racialized society, with racialization defining the emergence of racism as a tool to exclude (Moyo 2001). This became embedded in social practices and institutions throughout Zimbabwean society for at least a hundred years of colonial rule until independence in 1980. Racialization was a state-sponsored strategy of exclusion in which the overarching ideology was racial supremacy, where what was white, urban, educated and modern was supported while that which was African, rural and illiterate was underdeveloped. Through this ideology, most Africans were considered backward, ignorant and passive and were often treated in a condescending, paternalistic manner and were marginalized in all spheres of social life. The lifestyles of Africans and their (distorted) culture were considered inferior and given no recognition or space. A lopsided political economy resulted and with it came massive resource inequality, the cultural denigration of African ways of life, and ideas about femininity and masculinity would also change to accommodate the changes in social structure.

11 This racialization has not been a constant ; it changes with changing environments to safeguard the interests of the dominant group (Moyo \& Kawewe 2002) and intersects with other categorizations of people, i.e. gender, ethnicity, class, region, marital status and age. It is important to note that, through oppressive relations with people of European descent in Zimbabwe, African ethnic groups generally lost authority to explicitly define their values, their traditions and customs and therefore to maintain societal sanctions against inter and intrapersonal violence. Historically, since the national policing system in Zimbabwe was developed in a racialized environment to 
control and police Africans, there is a general lack of trust in these systems when it comes to curbing violence, and often Africans as individuals confronting interpersonal and intrapersonal violence have to take individual and/or group actions to protect themselves.

African ethnic groups in Zimbabwe are largely seen in the social sciences literature as patrilineal and collectivist in their family ideological outlook (Parpart 1995, Riphenburg 1997). Gendered role expectation is part of the expressions of family ideology, for males the breadwinner role is emphasized and for females the responsibilities are related to care even though women are expected to be economic providers too, and gender dynamics have evolved with the institutionalization of westernity. Elders in families are supposed to receive acts of deference. Prior to colonization, gender roles had been fluid but the collision of African collectivist arrangements and the ideology of domesticity created different experiences (Gaidzanwa 1996). For example, during colonial governments, African men were forced to work for wages in the white cities, while their wives, daughters and sisters were required to stay home, illustrating the domestication of African women (Moyo \& Kawewe 2002). The settler economy catered mostly to the minority white population in Zimbabwe and the majority of the population, which is African, experienced dispossession. Because of the racialization of the economy, social care at state level was preserved for the few, African families have thus evolved as the social security for their members, providing the indirect sanctions and support of members but also providing a variety of necessities, for example, jobs, credit, capital, care for the sick and the elderly, emotional support, and companionship. Ideally, the interdependence of family members is emphasized and family members are expected to take care of each other. Remnants of reciprocal obligations of family members remain visible in the pooling of resources, with adults supporting the young in the expectation that the young will take care of the old (Moyo 2001). However, these relations are also marred in disagreement and conflict. Obligations are not only confined to parents but to siblings and extended family members and if one is perceived as successful, children may be fostered with relatives to allow opportunities for education and work. Family members working far away from home are expected to send remittances (Moyo 2001), but financial dependency in a collapsed economy traps some family members in violence.

13 Societal changes resulting from colonialism, urbanization, wage employment, migration, wars and political destabilization, economic restructuring, and the speed of globalization have created different environments according to people's expectations of one another. Many families with few economic and social resources reproduce their livelihoods in extreme indigence resulting in a strain in familial relations, particularly if members are not able to positively adapt to the normed cultural and gender role expectations. Instead of banding together, conflict in families may cause the separation and isolation of its members. For example, where the male's role was to protect family members, if this role is undermined men respond by using violence against family members to get whatever they want as is the case at micro level with the vignette shared here. Similar threads are observable at macro level with the current administration at state level.

14 The changes that occurred post independence were particularly related to policies of economic restructuring and present different sets of dynamics for families. At independence in 1980, radical policies were made by the new African government to 
counter the effects of colonialism in most areas of social life and blatant racism became intolerable (Bond 1999). It was clear that colonial capitalism had not served the majority of the people well, considering all the socio-economic imbalances during the colonial period. Expansion of governmental support in basic necessities including education, housing, health care, sanitation and water became increasingly noticeable in post-independent Zimbabwe. Direct investments in people were seen to be essential for the social development of the economy. Generally, there was improvement in the quality of life for many after independence, a situation that would be reversed in the 1990s with the institutionalization of structural adjustment programmes that pushed for privatization and market-based solutions in all areas that were subsidized by government. The decommodification of some basic necessities had ensured improvement in the quality of life, for example, in education, health care, housing and prospects for social mobility by removing subsidies, but poverty escalated (Bond 1999). While concerns were about growth, equity issues and nation building, the ZANU-PF led government sponsored atrocities along ethnic lines, attacking the Ndebele as a minority ethnic group in Zimbabwe. In the international arena, problems of state violence, like the Gukurahundi atrocities, were not a topic of public discussion as the international community busied itself with shaping Zimbabwe as a model of smooth transitioning from white settler rule to independence. The extent and consequences of this violence remain a major public health issue.

Political economic changes in the 1990s, particularly the restructuring of the economy in an attempt to align the Zimbabwean political economy to westernity, also brought concerns that impact all levels of Zimbabwean society economically, politically and socially. The push for privatization saw the dismantling of many state-owned businesses. The process of privatization occurred within a stagnating economic environment that resulted in a dramatic reduction in the quality of life for many. In the process of restructuring, public companies were privately transferred to individuals as private properties and the capital was siphoned off. Bankruptcies followed and many people lost their jobs and subsequently their personal dignity as employment disappeared and incomes fell dramatically (Bond 1999). The resulting massive unemployment and increases in the prices of basic commodities led to protests and sometimes violent confrontations between the state, workers and students. The unemployment situation has been depressing for youths who have just completed high school and college through expanded education opportunities: this population, although educated, still cannot find employment. Shattered expectations are a form of violence as they undermine a person's physical, psychological and social health.

Increasingly, Zimbabwean youth were entering a job market that only offered positions as informal workers, if they could get the capital to start even that kind of work. Many migrated to countries where capital was seen to be concentrated. But even there jobs available to non-citizens are often at the bottom end of the service sector, and as such the generation that came to adulthood in post-independent Zimbabwe has not been able to realize the value of its education and has experienced an assault on their human dignity. Men and women sought jobs outside Zimbabwe but the service economy in areas where capital is concentrated usually prefers women migrants. Men's insecurities have mounted as they were expecting to find employment. In the lopsided economy, gender discrimination favoured males while women had cultivated self-employment, and with the contracting economy were able to provide their own work (Moyo 2001). Even though such work is confined to the lower rungs of the economy, it has provided a 
means of survival. Male workers suffered most in the economic restructuring because of their reliance on paid work (Moyo 2001). Massive unemployment and shattered expectations have resulted in frustrations and powerlessness which have been translated into emasculation (Fourie 2004), and led to a rise in self-destructive behaviour (such as alcoholism) and violence against elders to prove their masculinity where they have failed to meet familial expectations. With the breakdown of the economy, older adults are the ones with some assets and resources, and have at least had jobs and managed to accrue resources that can be translated into money. However, younger adults are the ones who are being heavily victimized by the collapse of the economy. They have no jobs and few sources of income and have to rely on older adults in the community. This has created massive familial tensions and interpersonal violence, where culturally, care was expected by older adults from the younger generation. The burden of care today is falling heavily on aging parents. Added to this is the AIDS/HIV pandemic that is killing the younger adults, and care for them is also increasingly falling on the older adults. When they die, orphaned children often remain in the care of older adults who will probably not have anticipated outliving their own children let alone grandchildren. Because of the absence of any public support, older adults are the only safety net for their families. People's scarce financial resources are being used up to cover basic necessities and this means that money tensions have also mounted as family members compete for scarce resources.

These problems have largely been played out as individual private problems because community protest has been met with an unsympathetic response from government officials who have used coercive strategies to redistribute land, as is seen in the government-sponsored commercial farm invasions (Chitiyo 2000). The current dynamics of the Zimbabwean political economy reflect and entrench structural violence, which is expressed in some situations as family violence, taking the form of violence against the elderly and family members. Sometimes the violence is "silent ", at other times it is "loud" (Ibid.). Violence against elders as part of family violence is a subject that is rarely talked about in public. There has been considerable discussion and efforts to stop domestic violence, particularly violence by domestic partners be they married or in live-in partnerships. Extensive efforts have been mounted to stop violence against children but violence against elders remains a silent subject. Hidden from the public is the violence against men, particularly in terms of material deprivation within a patriarchal-dominated society.

Surviving structural violence : A case study of a family coping with family violence by a young male adultThe historicized experience of structural violence

18 MaMlilo had been married to Moyo for forty-five years. At the time of the interviews Moyo was in his mid-sixties and was retired from the Zimbabwe national army and owned a small construction business. Like many of his generation, he had been forced to take up arms in the liberation war in an attempt to dismantle the racialized political economy. Moyo talks about a political economy that greatly disadvantaged Africans. In his younger adult life he had been a labour organizer and attempted to politically engage the settler governments into realizing the sculpturing of inequality but since the inherited Zimbabwean solution has never been to seek justice, to instil respect for dignity and protect those who were vulnerable, he had been tortured and imprisoned for organizing for change. Moyo and his family had survived the structural violence in silence but the forcible removal of their lands to make way for white farms left his family with limited means to earn a living and was done with such brutal force that the 
violence had moved him to join the struggle for independence. It is under these conditions that Moyo joined the liberation struggle to dislodge coercive settler rule. State-perpetrated violence has been Zimbabwe's heritage (Sokwanele 2006).

Talking about the effect of this violence, Moyo describes the separation from his family as a bad time in his life because he was not part of his children's lives as they were growing up, an issue now being raised by his son. A difficulty for Moyo was going against what he perceived as the norm, «a man takes care of his family and 'trains' the sons to take care of themselves. Instead of engaging in the personal development of his family he had to make sacrifices (of which he is proud) to become a freedom fighter. Being in the army Moyo learnt that power is gained and retained by the use of brute force. After independence, he stayed in the army as he had no other means of earning a living, but being stationed in another part of the country was devastating for him. In his words : "I had to leave the army as soon as I could get a reasonable pension and I wanted to become a family again. » This conversation highlights that the expectation was that both parents would help with parenting but because of employment opportunities families ended up divided, with husbands rarely sharing in the raising of their children. Apparently, families experience silent violence when spouses are not able to share parenting. This would be a point of contention in Moyo's family as husband and wife MaMlilo perceived the difficulties with their son Dingi as emanating from the absence of male authority in the home.

MaMlilo, a feisty 56-year-old woman, raised her five adult children: three girls are living and working in South Africa, one older boy who still lives at home, as do a younger boy of ten and several grandchildren. We started the conversation about the well-being of children. Moyo's family was raising four grandchildren and a "troubled and troubling adult son" was living with them. "Troubled and troubling" were Moyo's words to describe their son, Dingi, who was 26 at the time of the interviews and living with his parents, and had a girlfriend and a two-month-old baby. Three of the grandchildren belonged to the daughters who were working in Johannesburg and providing well for their children and Moyo and his wife. In MaMlilo's words : "my girl children were born with free spirits and it helped that they matured at a time that the government was promoting women's liberation... I rely on those girls as if they were men. That is what I keep telling Moyo that today it is not the male children who make homes it is women. It is better to have daughters : they work for their children and support them. I can never go hungry as I eat with the grandchildren. But with the boys it is different they never go anyway instead they bring trouble to us". The trouble referred to here is the silent family violence because the son is unable to meet family expectations. The question that is raised here is that male children have been unable to figure out ways of engaging in government-sponsored women's liberation. As the vignette unfolds we learn that MaMlilo's definition of family violence largely hinges on the son not following expected family roles. In this case, unlike the daughters who have managed to take care of their parents, the son was shaming the family by not adopting the role of "helpful" son. We see violence as expressed in the inability of the son to follow family roles, a definition of violence that is often hidden when the focus is only on physical and visible violence.

21 MaMlilo extended the definition of violence to include physical and psychological abuse they as adults had endured. MaMlilo in her spirited manner began to tell her story of coping with abuse from their son. Evidently, Dingi is the older boy in the family 
and as such had been the favoured child, a son who would carry the family name. MaMlilo explained: "Perhaps I treated him differently because I was proud to have a boy. It used to be that boys where the ones who would take care of us older parents. It used to be boys marry and their wives take care of us because girl children join other families. The saying was that boys build a home. This is how I treated my boy Dingi. I had expected him to be that home builder. I protected Dingi even in school when he got into trouble and was beaten, I would argue for him". Clearly, the expectation in this family was that male children were supposed to care for the family and aging parents, but this expectation is undermined in MaMlilo's family, as their older son Dingi is seen as irresponsible. However, the blatant preference for female children as models of success and responsibility means a revision in family ideology. But this revision does not appear to be going smoothly as it presents familial problems that intensify the silent violence. In MaMlilo's family the male child is no longer seen as an asset because he is unable to secure economic advantages and become a future provider. This gender role incongruence acts as an underlying factor in the violence between an adult male son who perceives emasculation and is unable to fulfil the expectation of the continuity of patrilinity. Instead, female children have become a family asset, and bearing children out of wedlock is no longer a shame but offers continuity of families by providing grandparents with grandchildren who can look after them in their old age. In the case of MaMlilo, her daughters' marriage and/or attachment to a male without secure economic standing was seen as a liability. The unkind treatment of Dingi's girlfriend by MaMlilo, as an elder, may exemplify the revisions in gender expectations. Troubling moments raising boys

Apparently both Moyo and MaMlilo had come to the conclusion that raising boys was a challenge after the frustrations they felt with Dingi. He had completed his high-school education and passed only a single subject although five passes are usually required for any further training. He had repeated his $O$ level exams twice and had done poorly each time. In school he had been a boy who was often humiliated and in his younger years his mother had been his protector. Seeing that he was not gifted academically, his parents tried to push him towards being a mechanic's apprentice. Evidently, Dingi had the support of his parents who tried to help him become a successful child by supporting his education. Besides his personal difficulties in school Dingi is among the many graduates who perceive themselves as the "sacrificed generation" who lost out on employment opportunities and whose education could not be translated into jobs and earnings because of the collapse of the economy. The only jobs available to Dingi and many youths were in the informal sector and were unappealing because of the precarious nature of the work and the low wages they offered. Shattered job expectations have left Dingi confused about his purpose in life.

However, Moyo, as part of the cohort of older adults who had secured resources before the collapse of the economy, managed to run his one-man construction company and had even tried to entice Dingi into becoming part of the company. To this, Dingi was reported to have explained to his parents that he was not interested in becoming a dagga boy meaning the one who lifts the brick-layering mortar. Evidently, Dingi had anticipated an office job and not manual labour. His parents were troubled by his lack of job and income so they tried to find him work. His mother had provided money for him to try his luck in South Africa as his three sisters had found employment there and were able to send remittances. Job prospects were perceived as better but Dingi was 
unlucky as he got deported several times. He suffered the humiliation of being rounded up, beaten and tortured by the authorities, so that he would never think of returning.

Apparently, the violence and humiliation had not been a deterrent as Dingi tried to re-enter South Africa several times before he gave up and came back home. On his return his father managed to find him a job through his contacts as a general hand in a small company making plastic products. At the time of the interviews (1999-2000), both his parents were afraid that Dingi would not keep his job because he had problems interacting with people and was drinking and gambling a lot. On one of my visits to Moyo's house I experienced firsthand the contempt Dingi had for people around him. He had airs of self-importance, and one Saturday morning that I visited his family he was still asleep around $11: 00$ a.m. His ten-year-old brother explained that he had come home drunk at 3:00 a.m., not caring that he had a small child. When he got home he had started fighting with his girlfriend. It had been quite difficult to quieten Dingi down. MaMlilo complained "you have seen with your own eyes this is what he does, wakes up late and eats, gets cleaned up and is out again until midnight or the early hours of the morning. He comes home when we are all asleep and expects us - his old parents - to get out of bed, unlock the doors for him and serve him hot food. If we don't, he starts his routine of insults and threatens to beat us" This is the silent violence that the family has endured. Dingi seemed grouchy and never seemed to have any sustained interaction with his family. The son's behaviour troubled the father who blames the inherited violence that forced him to leave his family. Moyo shared that at some point Dingi had begun to harass his mother for money, this was called "loud violence". When this happened Moyo had confronted Dingi who began to threaten his father with gangs. The father would not be a physical match for his younger son so they conceded and gave him the money he needed to avoid insults and threats, the "silent violence". At the time of the interviews Moyo was anxious and afraid that somebody was going to get hurt one of these days because Dingi was out of control. In Moyo's words, "it has been troubling and troubled moments raising boys".

Dingi young brother related another incident. MaMlilo had been born into a large family and her extended family supports each other. One of her sisters had an adult child who has been in and out of the hospital because of AIDS. In the ten-year-old's words: "Our mother had not been to the hospital to visit our cousin because she was not feeling well herself ... every adult has to visit those who are ill." Dingi's younger brother explained that one day he was in the city centre with his mother and they met the relative who had been hospitalized. "It was the three of us, our mother, Dingi and me. I remember now he had to help with finding mealie meal and carry groceries that is why Dingi was with us. On that trip we met our sick cousin and our mother gave him some money excusing herself that she was not able to visit him in hospital. After leaving the sick cousin, Dingi jumped on our mother with words demanding why she had given money to the sick cousin yet she had never given him anything. That afternoon mother avoided what would have been a potential confrontation in public with Dingi by just brushing his complaints off". In the younger brother's words : "I was afraid that if she tried to reason with him he would start beating our mother right there on the street. Although we are born and raised by the same mother and father and we have been taught the same lesson to respect our elders, Dingi is different. He is my older brother but I am afraid of him now. He was not always like this". The silent violence is mainly psychological abuse and the fear that familial role incongruence would be replaced by loud violence, the actual physical beating of the elderly mother. 
Seeing the boy's distress, Moyo injected, "you see even his young brother is now afraid of him. He used to be an aloof child growing up. Always punished in school, humiliated by other children but we never thought it would come to this. His girlfriend has been hit several times. I am sure that child is asking herself many times why she attached herself to him. As we said, he works but we have never seen a cent from him. After he gets paid he goes out drinking in pubs and clubs. We don't know what is going on with him because now even the cries of his baby make him angry. Can you imagine even the cries of his own child make him all mean ?» Moyo continued to describe the efforts they had made to help their son «MaMlilo and I have tried to take him to traditional healers (kubosiyazi) to understand what is going on with him. When we give him the medicines to cleanse him, he has attacked us for bewitching him. However, we know that the bewitching thing here is alcohol and it is shattered dreams that are destroying our son".

Clearly these parents were distressed by the actions of their adult son. MaMlilo and Moyo in their narrative gave an impression that they were interested in protecting their children. They had wanted the best for their children and were now frustrated about a son who had not embraced their efforts. Because he was no longer a child the parents had indicated that they had reported him to the police on several times when he had physically assaulted them. MaMlilo's words, "we report him to the police so that they could help us by talking sense to him because he does not listen to us anymore but we are afraid to let him go to prison. So, we are forced to find the police when things get out of hand, then he promises to listen and not repeat his deeds. We accept his apologizes and then he goes drinking and it starts all over again". The police are used to finding ways to punish people but in prison there is no way of undoing the embedded structural violence. At the time of the interviews Dingi's parents were hoping that he would move out of their house and the situation with his girlfriend having a baby seemed to suggest that perhaps he would move on. At the same time, his drinking and reliance on his parents suggested that he was home to stay. In his parents' home Dingi was demanding money not only for his upkeep but often for his drinking. Abuse of one's elders in the form of financial abuse is apparent in MaMlilo's words: "he comes at one o'clock in the morning and he will knock and demand that we get up and open the door. He knows that it is not safe around here and we are elderly and afraid of tsotsi (gangs of thieves) but still he does not take this into account. When he comes in the middle of the night he demands food. And when there is no food for him he becomes very aggressive. First it was banging of doors, then throwing things around, then it came to be targeted at me as the person who keeps the house. He does not wake up until noon. And when he is up, all of us and the younger children have to be walking on egg shells fearing that our moves will anger him".

Apparently, Dingi had physically pushed his father and threatened the younger children as well. MaMlilo explained that to try to keep the peace in their house they had tried giving him what he wanted - usually money. But whenever they were unable to, he would become verbally abusive particularly towards his mother who after trying to cleanse his spirit was accused of bewitching him, and this was why he was experiencing problems. The mother, in addition to keeping house and providing food, is also expected to have positive aura to enable children to be come successful. Yet when she tries to rely on traditional healing, these activities are perceived as bewitching and the violence escalates. MaMlilo explained that relations with her son became tense after his girlfriend got pregnant and moved into MaMlilo's home. In 
MaMlilo's version of things, the son and his girlfriend were not helping with the household chores or with the care of the grandchildren but expected her to work for them. MaMlilo felt that this was offensive because younger adult children were supposed to revere older people. MaMlilo explained that whenever she demanded that the daughter-in-law help, Dingi would be offended and to show his disapproval of his mother would shove her and shower her with insults. Sometimes the tensions escalated into violence, with the son using physical force against his mother and she, in turn, using objects to fight back. Again, MaMlilo explained that it was on these occasions that they reported him to the police but for fear of him ending up into prison, she had often dropped the charges. She explained that her son had pushed her too far and after the next incident she would be likely to have him arrested. It turned out that MaMlilo feared her daughters' disapproval if her own son were sent to prison as a result of her actions. In her words : "I am afraid of sending him to prison, I am afraid that the other children would not understand why his mother sent their brother to jail".

Voice of the presumed perpetrator of violence against the elderly, the son

Dingi complained that he did not have a secure job and this was frustrating. Casual employment meant that he was not able to meet his financial needs and those of his new family. In his words, "one feels hopeless, you work but the pay is little, things are expensive, prices of things go up everyday and then you come home and parents are at you for being a failure it gets difficult to handle. I know I have done wrong with the loud violence, fights and insults". While the precipitating factors for violence against his parents related to money matters, Dingi apparently felt that parental stress about being a failure resulted in arguments that escalated into violence. He recognized that his response was wrong but his alcohol consumption, which he did not see as a problem, usually led to the verbal and physical violence.

Because of his lack of resources and his continued reliance on his parents, Dingi felt that his mother was discriminatory against his girlfriend and that she had favourites among her daughters. He said, the care is with those who bring in hard currencies at the end of the month. Those of us without rands become nothing in this home.» The tensions of resources and status inconsistencies are poignantly highlighted in MaMlilo's son. When Dingi does not have rands (foreign currency) to contribute to his parent's house, he uses violence to assert the resource power that he does not have. Dingi justified his 'temper' as he described his behaviour towards his mother and related an incident that touches on status inconsistency and silent violence. "One day I was coming from town and I met mother with a neighbour and they were clearly talking about us children and mother boosting how her girls had been successful and when I approached them, mother did not even introduce me as her son, which shows that she does not like me but likes her girls. To be unacknowledged by your own parent as part of her family is humiliating.

30 To complicate the situation, I later learnt that Dingi had been coping with the realization that he was HIV positive. The unsettling issue was that his private troubles created havoc in the family and family members were only addressing the presenting violence. Dingi survived by acting tough and drowning his sorrows in alcohol but in the process has become a menace to everyone in his family.

Summary and conclusion

31 Violence has to be understood within the context in which it unfolds. In this case, the family is a power system embedded in the constellation of an inherited history of 
violence - the context of the political economy of Zimbabwe. - and structural violence becomes entwined in familial relations. When a family member does not have resources, or their status is undermined, they will use violence to assert power. The absence of resource ownership among young adults, as illustrated in the example, means that young adults like Dingi turn to their parents for support while the expectation is that older adults would turn to younger adults for support and protection. If Dingi's drinking and gambling habits are not satisfied, violence and threats are used to exhort money from those who are perceived as having it. Family violence is expressed in silent violence in the form of threats, shaming and humiliation but this can escalate into loud physical violence.

The case here not only explains conflict in family ideology where a son - because of the privilege of being male in a gendered society - is supposed to provide honour to the family by showing responsibility and protection for parents and females but also the fact that Zimbabwean society is plagued by violence. At both the micro familial level and governmental level, the use of violence is apparent. The son suffers status inconsistency as a result of widespread unemployment and low wages and this leads to the use of violence to assert the authority of maleness in the family. Yet because of societal changes, the son finds that the family ideology is revised and he has difficulties coping with the new expectations. His mother - as the family protector - does not make it easy, and so the violence escalates.

The revision of family ideology within a social environment marred by violence and poverty is felt negatively by the son, who sees himself as losing ground as a result of the changes : a young adult male is no longer sure what his role is since male authority is challenged by female resource ownership. MaMlilo, the older woman, does not hide the failings of her son and even discusses the situation with neighbours. The silent violence goes both ways. The older parent preferred her daughters to her male child who was seen as "being a trouble and creating troubles" instead of contributing to family well-being. Failure to fulfil his manly role is not only a family issue but is shared in the community, leading to the son's loss of standing in his immediate family but also in the extended family and among neighbours. The loss of this power is compensated for by the use of violence to assert power and get the resources he needs.

The decrease in opportunity and resource availability in the Zimbabwean political economy has resulted in rampant social violence as people try to survive the brute of indigence. The link between familial violence and poverty is shown in this case. While poverty is extreme, societal change has meant that traditional gendered mores are also being challenged. Although the situation of the daughters in the family narrative presented here is not elaborated on, the mother's fear of sending her son to prison speaks to further psychological abuse of elderly parents who fear a loss of familyhood if the son is incarcerated. The threat of losing that family - particularly her daughters' material support in an environment where there is hardly any social care system for the elderly - leads elderly parents to suffer abuse in silence. Both parents were resourceful in trying to find ways to support their son and to understand his problems but given the social environment that has a history of violence and no visible means of containing the violence, it is difficult to extricate oneself from self-destructive habits. We conclude that the lack of sanctions against structural violence in Zimbabwe's political economy highlights a defect in society's mechanisms to address social justice. 


\section{BIBLIOGRAPHIE}

Bond, P., 1999, 'Political reawakening in Zimbabwe', Monthly Review, 50, 11, p. 1-17.

Campbell, J.C., 1992, 'Wife battering : Cultural contexts versus western social sciences', in : D. Ayers Counts, J.K. Brown \& J.C. Campbell (eds.), Sanctions and Sanctuary: Cultural Perspectives on the Beating of Wives, Boulder, Westview Press, pp. 229-249.

Chitiyo, T.K., 2000, 'Land violence and compensation : Reconceptualising Zimbabwe's land and war veterans', CCR-Track Two, 9, 1, p. 1-31.

Concha-Eastman, A.J., 2001, 'Violence : A challenge for public health and for all', Epidemiological and Community Health, 55, p. 597-599.

Fourie, R., 2004, 'South Africa', in : K. Malley-Morrison, International Perspectives : Family Violence and Abuse: A Cognitive Ecological Approach, London : Lawrence Erlbaum Associates.

Gaidzanwa, R.B., 1996, 'The ideology of domesticity and the struggles of women workers in Zimbabwe', in : A. Chhachhi \& R. Pittin (eds.), Confronting State, Capital and Patriarch : Women Organizing in the Process of Industrialization, London : Macmillan, pp. 273-289.

Gil, D.G., 1998, Confronting Injustice and Oppression : Concepts and Strategies for Social Workers, New York : Columbia University Press.

Goode, W., 1971, 'Force and violence in the family'. Journal of Marriage and the Family, 33, p. 624-636.

Malley-Morrison, K., 2004, International Perspectives : Family Violence and Abuse : A Cognitive Ecological Approach, London : Lawrence Erlbaum Associates.

Mandaza, I., 1986, Zimbabwe : The Political Economy of Transition 1980-1986, Dakar, Senegal, CODESRIA.

Moyo, O.N., 2001, 'Dealing with work in its context : An analysis of household work and provisioning strategies in Bulawayo, Zimbabwe', PhD Thesis, Heller Graduate School, Brandeis University.

Moyo, O.N. \& S.M. Kawewe 2002. 'The dynamics of a racialized, gendered, ethnicized, and economically stratified society : Understanding the socio-economic status of women in Zimbabwe', Feminist Economics, 8, 2, p. 163-181.

Okulate, G., 2005, 'Interpersonal violence cases reported to the police : A Nigerian Study'. Journal of Interpersonal Violence, 20, 12, p. 1598-1610.

Parpart, J.L., 1995, 'Gender patriarchy and development in Africa : The Zimbabwe Case'. Working Paper, 254. East Lansing, Michigan State University.

Riphenburg, C., 1997, 'Women's status and cultural expression : Changing gender relations and structural adjustment in Zimbabwe', Africa Today, 44, 1, p. 33-50.

Sokwanele, 2006,'Zimbabwe's heritage of violence' : Sokwanele comment on the $26^{\text {th }}$ anniversary of independence. Zimbabwe : Sokwanele Civic Action Support Group. http ://www.reliefweb.int/ rw/RWB.NSF/db900SID/YAOI-6NZ3LX?OpenDocument. Retrieved 15 June 2006. 


\section{RÉSUMÉS}

Titre: Survivre à la violence structurelle au Zimbabwe: Étude de cas d'une famille affrontant la violence. Cette contribution discute de la relation entre la violence structurelle et celle sociale au Zimbabwe. La violence doit être comprise dans son contexte. Dans ce cas spécifique d'une famille zimbabwéenne, les relations familiales peuvent être considérées comme des relations de pouvoir, dans un contexte politico-économique marqué par une histoire de violence. Une violence structurelle qui se retrouve entremêlée dans les relations familiales. Quand un membre de la famille n'a pas de ressources, ou que sa position soit ébranlée, il usera de la violence pour affirmer son pouvoir. L'absence de ressources matérielles pour les jeunes adultes, comme illustré dans l'exemple, veut dire que ces derniers se tournent vers leurs parents pour un appui alors que l'attente est justement le contraire, c'est-à-dire que les parents se tournent vers les jeunes pour chercher appui et protection. Si la soif d'alcool et des habitudes de jeux n'est pas assouvie, alors la violence et les menaces sont utilisées pour soutirer de l'argent de ceux dont on pensent qu'ils en possèdent. La violence familiale s'exprime de façon silencieuse sous forme de menaces, de brimade et d'humiliation, mais cela peut se transformer en violence purement physique.

This article discusses the relation between structural and social violence in Zimbabwe. Violence has to be understood within the context in which it unfolds. In this case of a Zimbabwean family, the family is a power system embedded in the constellation of an inherited history of violence the context of the political economy of Zimbabwe. - and structural violence becomes entwined in familial relations. When a family member does not have resources, or their status is undermined, they will use violence to assert power. The absence of resource ownership among young adults, as illustrated in the example, means that young adults turn to their parents for support while the expectation is that older adults would turn to younger adults for support and protection. If drinking and gambling habits are not satisfied, violence and threats are used to exhort money from those who are perceived as having it. Family violence is expressed in silent violence in the form of threats, shaming and humiliation but this can escalate into loud physical violence. 